\title{
The Role of Catholic Church in Improving the Quality of Human Resources in Diocese Ruteng-Indonesia
}

Salesman F1*, Tapung MM² and Gobang YKGD ${ }^{3}$

${ }^{1}$ Citra Nation University, Indonesia

${ }^{2}$ Sint Paul Universtity, Indonesia

${ }^{3}$ Nusa Nipah University, Indonesia

\section{Case Report}

Volume 2 Issue 6

Received Date: October 16, 2019

Published Date: November 01, 2019

DOI: $10.23880 /$ jqhe- 16000143

*Corresponding author: Frans Salesman, Lecturer at Citra Nation University, Manafe Street 17 Kayu Putih Oebobo Kupang-East Nusa Tenggara, Indonesia, Tel: +6281237928225; Email: franssalesman@gmail.com

\section{Abstract}

Background: The Catholic Church in Diocese Ruteng is 107 years old. The spread of Catholic religion has grown with the number of followers of $87.95 \%$ of the total population. In addition to the spread of Catholicism, missionaries opened institutions for education, health, and economic empowerment of their people.

Purpose: This study revealed the role of missionaries in Diocese Ruteng to increase HDI (Human Development Index) in their region.

Method: Using descriptive analysis with triangulation approach, publication data of the Nusa Tenggara Timur Statistics Agency, Catholic Church documents, and media publications about the performance of missionaries in Diocese Ruteng Results. The average school years of residents aged 10 years and over in 2015 amounted to 6.69 years, 2016 amounting to 6.74 , on 2017 amounting to 6.86 years. The average life expectancy in 2015 was 65.94 years, 2016 was 66.41 years, and 66.48 years. The average per capita expenditure for 2015 is IDR (Indonesian Rupiah). 6,377,000, 2016 IDR. 6,517,000, 2017 IDR.6,623,000. Average HDI, in 2015 amounted to 59.37, in 2016 amounted to 59.90 years, and 2017 amounted to 60.93 years.

Conclusion: The Catholic Church in Diocese Ruteng for 107 years has played a role in increasing HDI in its territory. The challenge of cyber technology is making the church act as a balancing agent so that Catholic faith is not eroded. Emphasis on sacramental services is improved along with diversification of educational services. Health and economic strengthening.

Keywords: Catholic Church; Role; Human Development Index 


\section{Journal of Quality in Health Care \& Economics}

Abbreviations: NTT: Nusa Tenggara Timur (East Nusa Tenggara); HDI: Human Development Index; SVD: Societas Verbi Divini (Latin) or United Word of God; ASEAN: Association of Southeast Asian Nations.

\section{Background}

The development of the socio-cultural and economic life experienced by the people in Diocese Ruteng is now the present as a segmentation of the evolution of humanity and the work of the Catholic Church of the Diocese Ruteng with the people and local government. Church work began at the arrival of Jesuit missionaries in 1910-1911 with the first baptism in Reo on May 17, 1912 by Pastor. Henrikus Looijmans SJ to Catherine (Arbero), Henricus, Agnes Mina, Caecilia Weloe, and Helena Loe koe. The annihilation event became the birthmark of the Catholic Church of the Diocese Ruteng. After the censorship at Reo, Jesuit missionaries handed over their missionary work at Diocese Ruteng to the Societas Verbi Divini (SVD) beginning in 1914. Di Ruteng, Pastor Petrus Noyen, SVD baptized the first Catholics in Pitak on December 14, 1914. Furthermore, his missionary work developed very fast. Until now, the area of Diocese Ruteng has an area of 7,136 m2, divided into 3 fronts, 76 parishes spread over three administrative regions of the Manggarai, West Manggarai and East Manggarai districts [1]. Until 2017, the number of Catholics in Diocese Ruteng was 767,384 people or $87.95 \%$ of the total population in the three districts amounting to 872,523 people spread over 5,671 Base Groups [2,3].

Hirakhi Catholic Church and its actors realize that humans are creatures of God's creation that have two main roles, namely as people in the sense of state administration and people in the sense of Catholic church administration. The quality needs to be continuously improved in order to be able to manage every opportunity and challenge in every stage of human civilization. The change in the service paradigm was developed through service diversification. The task of the diaconas originally held by obedientiary was only sacramental service as the core product of service, but in line with the development of civilization the deacon's duties were diversified with non-sacrament services to meet the physical needs of the people, namely services in the fields of education, health and economic empowerment.

\section{Purpose}

This paper is about the current portrait of the quality of Catholics in the Diocese of Ruteng with the main measure of the Human Development Index (HDI). The achievement of HDI as a result of scientific analysis is the result of the process of being attained by the Catholic Church since 1912. The development of the era continues. The church with all its attributes and actors has an active role in managing the management of the church and its people and extrapolating the future tendency with all its deviations so that the Catholic church remains a pillar in overcoming every problem in its people. Another part of this paper is a recommendation on strategies and policies on the development of Catholic resources that may be carried out together with regional governments in Diocese Ruteng in the future.

\section{Method}

Using deskripstif analysis research using main ingredients are statistical publications of East Nusa Tenggara and national mass media and local who wrote the text and content of news on the development of services for 107 years the Catholic Church and the HDI. The data triangulation method is used to compare data (cross check) from the development documents of the Catholic Church in Diocese Ruteng, literature studies and the coverage of mass media in Indonesia and locally related to Catholic church services, as well as the publication of the HDI analysis by the Indonesian Central Bureau of Statistics [4-7]. The observation unit is the development of church services until 2018, services in the fields of education, health, and economic empowerment of Catholics, as well as the HDI in Diocese Ruteng [8].

\section{Discussion}

\section{Indonesian Human Resources Competitiveness}

The government is building infrastructure and facilities for human life aimed at being able to be competitive at the national, regional and international levels. Building Indonesian people, including Catholic. In the same realm the Church builds the spiritual side of the people towards the full and mutual complementarity between body and spirit.

The state through the government as a tool for God to build humans aims to improve human welfare in an effort to preserve God's creation. Therefore, the Church and the state must work hand in hand in the effort to uphold justice and seek the welfare of all the people. But as an autonomous religious institution, the church carries out functions and authorities that are free from state influence, and conversely the Church has no right to regulate the life of the state because the state has its own 


\section{Journal of Quality in Health Care \& Economics}

function in carrying out its vocation in the world [9]. The Church is obliged to fight for and uphold human dignity as a person who is valued before God. The attitude and role of the Church are based solely on Christian motivation. Therefore the Church was concerned about poverty and underdevelopment which still suffered by many people. If for the sake of the development and protection of human values, the Church plays a critical role, it avoids confrontational actions and uses available channels and seeks to bear witness to the truth as a valued value [5].

In the efforts of development in all areas of human life, the Church sees its distinctive role in efforts to build a healthy mentality, provide the right motivation, foster an attitude of dedication and sincerity, contribute to the ethics of development and foster an optimistic attitude. Therefore the leadership of the Church expects all the faithful to engage themselves and be constructively critical, by honestly evaluating the goals and objectives of development and the efforts and ways of implementing them [10].

The implementation of multi-dimensional development by the government and the Church is intended so that none of the sectors that fulfill human needs are ignored. But, of course in the resource constraints, there is a leading sector as a locomotive to attract other sectors. The journey of human civilization is analogous to that of a train that runs its two rails to the destination station. Before arriving at the destination station, he stopped by the station by stopping with a certain duration and departing again until finally arriving at the destination station.

Photographing human quality like in Indonesia today depicts the transit station from a journey of the evolution of the quality of Indonesian people and their Catholics. At present, we have arrived at the cache station called Millennial or Four Point Zero (4.0). A new era, marked by technological advances in various fields, especially artificial intelligence, robots, block chain, nanotechnology, quantum computers, biotechnology, Internet of Things, 3D printing, and unmanned vehicles [11]. In era 4.0 there was a rapid transformation in the production process. Originally using human power, now switch to using a machine. This causes goods to be produced in bulk in large quantities with a relatively short time. The rapid and rapid development of science and technology today is able to influence and change the way of life, how to work, and how to relate to one another. The transformation of civilization is very fast penetrating the joints of social life [11].
The transformation of technology with various associations directly or indirectly influences patterns of behavior and social interaction. Humans become servants of technology override their existence as social creatures created by God. Deviation is happening everywhere. It even becomes pathological endemic which massively undermines the life structure of society. Communication relations usually use oral and face to face, replaced by Short Message Service (SMS) and Video Call. News of death events or customary affairs, usually using missions (wero=in Manggarai Language) now enough to be made in Face Book status or on Wathsapp messenger, all members of kinship come to the scene. Humans are increasingly spoiled by technology. Decreasing competitiveness that must grow and develop in a person. Pathological symptoms also occur in students and students. They do not have to bother buying books in bookstores, just buy an Android handphone all communication needs and knowledge narratives obtained through the mobile technology application. The ease provided by communication technology in social interaction and teaching and learning processes has an impact on the waning of one's fighting power in overcoming life problems.

The high dependence of life on communication technology affects the expenditure structure in the family. The procurement of communication equipment and the purchase of internet credit is a priority in the scale of meeting basic needs in the family. Shifting the priority of meeting essential needs, eating and drinking for child development, fulfillment of nutrition, and health care, purchasing clothes, and housing. Families with middle and low class incomes do not have the opportunity to save to pay for education to secondary and higher education. In East Nusa Tenggara, the average length of school until 2018; men 7.62 years and women 7.00 years, lower than the national average in the same year; 8.62 years old men and 7.62 years old women. The level of education influences the competitiveness of the nation's education [12].

The adaptation obstacle of revolutionary civilization 4.0 is that it is a ghost named poverty. Poor people have difficulty accessing education and health forming the quality of human resources. The low resource capacity of the poor creates new poverty for the next generation. Poverty is like a spiral that rolls along the life span of the poor. Poverty makes people not independent to position themselves to manage social opportunities. Poor people will have difficulty making economic, social and democratic investments. In the political sphere, poor people find it difficult to show electoral independence, 


\section{Journal of Quality in Health Care \& Economics}

tempted by the seduction of the rupiah that politicians hold on to. The phenomenon of exploiting the basic rights of the poor in any field becomes a new culture. Statistical data shows that the number of poor people (population with per capita expenditure per month below the Poverty Line) in Indonesia until March 2018 reached 25.95 million people $(9.82 \%)$ or decreased by 633,200 people compared to September 2017 at 26.58 million people (10.12\%) [10]. The number of poor people in Diocese Ruteng in 2018 was 149,050 people, $17.49 \%$ of the total population (Manggarai 69,320 people, West Manggarai 48,530 people, and East Manggarai 74,880 people) [1315]. The number of poor people in the Diocese of Ruteng contributed $13.05 \%$ to the number of poor people in East Nusa Tenggara of 1,142,170 people. The high rate of poverty in Indonesia, including in East Nusa Tenggara, has resulted in a low Indonesian education index compared to neighboring countries in ASEAN. 2017 Human Development Reports states that Indonesia's Education Index position of 0.622 is ranked seventh in ASEAN. The highest score achieved by Singapore was 0.832 , followed by Malaysia 0.719, Brunei Darussalam 0.704, Thailand and the Philippines both had scores of 0.661, Camboja 0.487, and Laos 0.485 [8]. Independent variables formed educational competitiveness, namely; formal education and vocational education, literacy, university/ institute/polytechnic/high school rankings, scientific journals and publications, students studying abroad, the number and types of research. Does the church turn a blind eye to this fact?.

The deacon's role in the church must be present as a catholic in the above phenomenon. The role of the church and Catholics can provide solutions to overcome poverty, reduce the number, so as not to get bigger, this requires education, skills, helping the rich for working capital, opening employment, providing skills training to earn money. In the midst of society, the problem of poverty is found in all regions and due to difficulties due to the high prices of various needs and low income of the community, poverty is like a vicious circle, difficult to overcome, but can be reduced, and instill diligent, diligent, resilient, skilled, willing to work hard and don't forget faith in God [10]. In accordance with the attitude of Jesus Christ in His shepherding, as a patron for the Church to show solidarity with the poor. He helped all the less fortunate without discriminating between tribes and religions in his time [16]. Self-strength is developed, but the points of weakness must be destroyed first, such as lazy, reckless, careless, unskilled, lack of education, wasteful, and so on. But what is important is let's find a solution, especially God's people can be skilled in educating their people, analyzing the causes of poverty, finding a way out, so as to reduce poverty, improve living standards and increase the income of Catholics [17].

\section{Competitiveness of Catholics In Diocese Ruteng}

\section{The Evolution of the Formation of the Competitiveness of the People}

The concept of competitiveness has become part of the diaconal duties of the Faith / Brothers / Sisters in Diocese Ruteng. They realized that without increasing the quality of human resources, the development of the Catholic church was only quantity oriented without being followed by the quality of Catholic faith. In 1913, the Dutch East Indies Government issued a subsidy regulation for schools in Flores. The regulation could be called FloresSoemba Regeling, renewed in 1915. With the new regulation, the Mission could establish new schools in central Flores, such as Ngada and Manggarai. The most schools are the 3-year-old People's School, which at that time was called the Village School. Aside from being a media of intelligence, the school is a tool that is considered effective for the mission to spread religion and deepen the faith of Catholic teachings. [11] Until now there are 300 schools under the auspices of the Sukma Foundation. Of these, there are 265 elementary schools, 18 junior high schools, ten high schools. Of all the schools, there is only one vocational school that is in the Sukma Foundation, namely SMK Stella.

In 1959, Pastor Jan van Roosmalen SVD opened a catechism course with his first lecture starting on November 11, 1959. Over time, this course was later transformed into a Catechetical Education Course, the Catechetical Education Academy and now the College of Teacher Training and Education and year 2019 has metamorphosed into the Sint Paulus Ruteng University $[12,13]$.

Vocational education for the formation of labor competencies has been a concern of Catholic missionaries for a long time. Construction of community houses and worship buildings is carried out with traditional technology. They opened an ambacht school or woodworking school in Ruteng and in Mukun, with majoring in woodworking, ironworks, and automotive workshop carpentry. In the 1980s survey and road and bridge skills courses were developed by Pastor Ernst Wasser, SVD and Pastor Stanislaus Ogabe, SVD. To date, ambacht school alumni and road / bridge management courses teach skills to their children as well as open government and private projects contracting companies. 
Maintaining and improving public health is an integral part of pastoral care. Catholic missionaries in carrying out the proclamation of the Catholic faith treat infectious diseases suffered by their people. They understand the types of diseases suffered by people in tropical areas are malaria, dysentery, worms, and anemia. The rectory house was used as a drugstore. Types of drugs sold; kinine medicine (treatment of malaria), worm medicine, fever-lowering drugs, and B-Complex vitamins. If you travel to schools or stations, medicines are stored in the box along with clothes and mass equipment. Medicines are given to the people who need them. Pastor Galus, SVD in Dampek and in Reo conducted counseling and treatment services at his residence. Until now, Sint Rafael General Hospital has been present in Cancar, Mother \& Child Health Center in Karot, and several mental institutions in Leda-Ruteng.

The economic empowerment of the people has long been the concern of missionaries serving in Diocese Ruteng. The missionaries realized without being supported by a strong family economy, families would not be able to build an independent church in the future. The church in Diocese Ruteng cannot continue to rely on the extension of operational and development financing from the mercy of donors abroad. The people economy needs to stand on its own feet.

In 1933 the Ruteng Catholic Social Brotherhood was formed, with a passionate encouragement from Pastor Adolf Burger SVD, the organization was moved by a Catholic figure from Java, named Eligius Suradjim Martawidagda. In the following years Pastor Theo
Thoolen, SVD founded a Teacher Cooperative in West Manggarai. In addition to buying and selling activities, the cooperative is intended to influence the development of prices. In 1940 Father Wilhelmus Van Bekkum founded in Mukun (East Manggarai) a good cooperative with similar objectives, in 1955, relying on the principles of Pancasila, the Church of Indonesia established various trade unions. In connection with that, Bishop Wilhelmus van Bekkum, SVD founded in Manggarai Pancasila Farmers Association which aims to participate in the development and development of the Manggarai community [11].

The four-dimensional service (sacramental, educational, health, and economic services) carried out by missionaries a hundred years ago, made Catholicism a part of people's lives in the Diocese of Ruteng. The Catholic Church has built four strategic dimensions of human essential needs. The consultant, of course, the increasing quality of Catholic resources is indicated through the index of human resources.

\section{Quality of Human Resources in Diocese Ruteng}

The HDI is one way to measure the performance of a country or region in the field of human development. HDI is a composite index covering three areas of human development, namely: indicators of health, level of education, and economy. The physical quality of humans is reflected in life expectancy, while non-physical quality is reflected in school expectations, the length of the average population in school, and considering the economic capacity of real per capita expenditure [14].

\begin{tabular}{|c|c|c|c|c|c|c|c|c|c|c|}
\hline \multirow{3}{*}{ No } & \multirow{3}{*}{$\begin{array}{l}\text { HDI Forming } \\
\text { Variables }\end{array}$} & \multicolumn{3}{|c|}{2015} & \multicolumn{3}{|c|}{2016} & \multicolumn{3}{|c|}{2017} \\
\hline & & \multirow{2}{*}{ Manggarai } & \multirow{2}{*}{$\begin{array}{c}\text { Manggarai } \\
\text { Barat }\end{array}$} & \multirow{2}{*}{$\begin{array}{c}\text { Manggarai } \\
\text { Timur }\end{array}$} & \multirow{2}{*}{ Manggarai } & \multirow{2}{*}{\multicolumn{2}{|c|}{$\begin{array}{c}\text { Manggarai } \\
\text { Barat }\end{array} \begin{array}{c}\text { Manggarai } \\
\text { Timur }\end{array}$}} & \multirow{2}{*}{ Manggarai } & \multicolumn{2}{|c|}{ Manggarai|Manggarai } \\
\hline & & & & & & & & & Barat & Timur \\
\hline 1 & $\begin{array}{l}\text { Avarage Length of } \\
\text { School (Year) }\end{array}$ & 6,81 & 6,81 & 6,43 & 6,97 & 6,82 & 6,44 & 6,98 & 7,14 & 6,45 \\
\hline 2 & Life Expectancy (Year) & 65,48 & 65,08 & 67,27 & 65,66 & 66,19 & 67,39 & 65,84 & 66,19 & 67,40 \\
\hline 3 & $\begin{array}{l}\text { Avarage Expenditure/ } \\
\text { Year/Cap (IDR.000) }\end{array}$ & 6.875 & 7.012 & 5.246 & 8 & 7.149 & 5.396 & 7.056 & 7.269 & 5.543 \\
\hline & HDI & 60.87 & 60,40 & 56,83 & 61.67 & 60,63 & 57.5 & 63,24 & 61,65 & 58,51 \\
\hline
\end{tabular}

Table 1: Development of HDI and its Forming Variables in Diocese Ruteng Region in 2015-2017. Source: Central Bureau Statistic 2015-2017

Human development in Indonesia continues to progress. In 2018, Indonesia's HDI reached 71.39 contributed by the average length of schooling of 8.07 years, life expectancy at birth 71.06 years, and expenditure of IDR.11.059,000 / capita / year. Indonesia's HDI number increased by 0.58 points or grew by 0.82 percent compared to 2017. In the same year, HDI East Nusa Tenggara reached 64.39 ranked 32 out of 34 provinces in Indonesia. HDI figures in East Nusa Tenggara are contributed by the average length of school of 7.30 years, life expectancy at birth 66.07 years, and expenditure of IDR.7,566,000 / capita / year. The average 


\section{Journal of Quality in Health Care \& Economics}

HDI in Diocese Ruteng in 2015 was 59.37, 2016 was 59.90, and 2017 was 60.93. Diocese Ruteng covers the administrative area of Manggarai, West Manggarai, and East Manggarai districts covering an area of 7,136 Km2 with 872,523 peoples [3]. The development of HDI in Diocese Ruteng in 2015-2017 is noted in table 1 above.

The figures listed in table 1 illustrate the development of HDI and its forming variables in Manggarai, West Manggarai and East Manggarai Timur districts which are included in Diocese Ruteng in 2015-2017. Grouping HDI in an area at a certain time is grouped into four groups. This grouping aims to organize regions into four groups, namely; (1) very high if $\mathrm{HDI} \geq 80$; (2) high if $70 \leq \mathrm{HDI}<80$; (3) moderate if $60 \leq \mathrm{HDI}<70$; and (4) low if HDI $<60$. If referring to the group category, then Manggarai and West Manggarai districts are included in the medium group, and East Manggarai into the low group.

\section{School Average}

If the average length of school year is analyzed, the population of the age of 15 years and over from the three kevikepan (Manggarai, West Manggarai, and East Manggarai) numbers is obtained in the following graph 1.

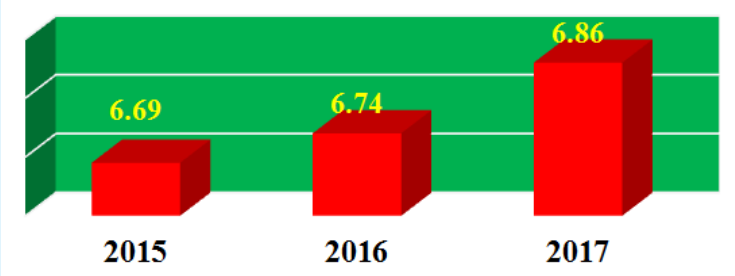

Graph 1: Graph of Average Development of School Year Population 15 Years and Over in Diocese Ruteng in 2015-2017 (Year).

Source: Analysis Result

In graph 1, the average length of school in 2015 of 6.69 years is lower than the average for the East Nusa Tenggara provincial level of 6.93 years, as well as 2016 for 6.74 years below the NTT figure of 7.02 years, and in 20176.86 is still below the NTT figure of 7.15 years. The low average length of school years is a challenge for the local Church in preparing the younger generation to face the demands of competence in the digital age. In the digital era, human work has been taken over by robots because it is considered more effective and efficient. Cyber technology dominates human life. Humans and machines are harmonized to find innovation and scientific problem solving. The increasingly dominant role of cyber technology in people's lives has created a trade off in the continuity of cultural ethically based values inherited from the ancestors of the Manggarai people. Deviative behavior appears according to the size of the norms and cultural values of Manggarai.

With the quality posture of education revealed in graph 1 above, the hypothesis of uncontrolled behavior deviations emerges even further from the tolerance threshold. This situation will be troublesome for educators and parents to teach attitude and independence values as the ultimate goal of the education process. Students are shaped by their personalities from cyber technology, including hoaxes that become public opinions that have not been tested for the validity and accuracy of factual truths. The principle of correspondence of information corresponds to the fact that it is getting farther away from communication behavior among humans. Social pathology caused by uptake of information technology not based on facts is a new symptom in society today.

The Church as an institution formed to uphold the values of truth in human life must be present to improve the social phenomena that occur. Formal and non-formal educational institutions together with the Catholic church must intervene to help restore the chaotic social situation. If left unfamiliar with the situation hypothesized above, it will become a new culture in the life of Catholics in Diocese Ruteng who are accustomed to the principle of upholding the objectivity and formal truths taught by the Divine Lord Jesus Christ.

\section{Life Expectancy}

Age of life expectancy at birth is the average year of life that will be lived by a newborn baby in a given year. Life expectancy is the average number of years of life that is still lived by someone who has reached a certain age. Life expectancy as an indicator of public health as a downstream measure of the success of health development and socio-economic development. Increasing life expectancy at birth illustrates the improvement of health status and socio-economic level of the community in a region.

Life expectancy as a composite number of combined infant mortality rates, illiteracy rates of people aged 10 years and over, percentage of infants aged 0-11 months given breast milk for 4-6 months, economic growth rate, percentage of infants aged 1-4 years who get complete immunization, and labor force participation rates. 


\section{Journal of Quality in Health Care \& Economics}

The development of the average life expectancy of the people in Diocese Ruteng during 2015-2017 can be observed in Graph 2.

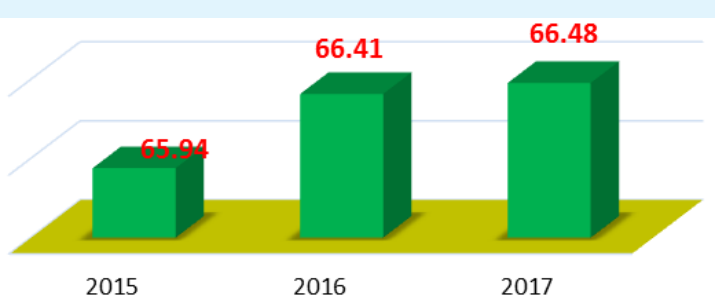

Graph 2: Development of the Average Life Expectancy of People in Diocese Ruteng in 2015-2017 (Year).

Source: Analysis Result

The results of the analysis of the Central Bureau Statistics of East Nusa Tenggara in 2018 showed that the average life expectancy of the people in Diocese Ruteng in 2015-2017 was 66.28 years above the average East Nusa Tenggara Province at the same time of 66.02 years, but below the average national amounted to 70.91 years [18]. The number of life expectancy 66.28 illustrates that the average Manggarai people cannot celebrate their 67th birthday because they have died before.

\section{Per Capita Expenditure}

Per capita expenditure is the cost incurred for the consumption of all household members for a good year originating from the purchase, giving and production itself divided by the number of household members in that household [14,15]. Household consumption is distinguished from food and non-food consumption regardless of origin and is limited to expenditures for household needs only, not including consumption / expenditure for business purposes or given to other parties. Expenditures for food consumption are calculated during the past week, while non-food items are calculated for the past 12 months. Both food and non-food consumption are then converted into average annual expenditure.

For the church and its people, the real purchasing power per capita has a strategic value in the development of the independence of the local church in the future. Various agreements on the amount of donations determined by the pastoral board at the parish level and base groups on an annual and monthly basis depend on the real power of the people. There is no denying that in measuring the size of the parish congregation's collection of prayers that occur in the district or city of the sub district, the number is greater than in the countryside.
Uniquely, the surface of the paper collected from the mass in the countryside is sometimes not clearly visible, the value is already worn out because it repeatedly moves hands from fish traders / meat traders to vegetable and rice sellers, from the seller of the coupons to vegetable farmers and cassava traders or vice versa. Transactions using worn money illustrate the people's economy is still traditional, far from banking. How unique is the transaction system using money in the economy of rural communities amidst the frenzy of millennial civilization that has used new money that may have just been withdrawn from the Automated Teller Machine or taken from a safe. The nominal value of the collection may range from IDR 1,000 to IDR 10,000 . If there is a collection of money that is found to be more than the usual amount, it is likely that the people will only get a profit, receive a monthly salary, or guests as mass participants from the city are visiting the village. This is a portrait of the village economy in Diocese Ruteng, where the majority of the people are Catholic.

The real power of Catholics in Diocese Ruteng on graph 3 indicates that the ability of communities to access available resources elsewhere is still low. The paradox phenomenon occurs in the Diocese Ruteng. Although the average real expenditure per capita with an average of IDR.6,502,110, per year or equal to IDR.17,814, - per day/capita during 2015-2017, the figure is lower than the price of one pack of cigarette warehouse salt in shops, but the majority of the Diocese Ruteng people have arrived in villages that have mobile phones to communicate with members to their relatives outside the area. With video call communication it is not possible to cheat on the other person that he is in another place when the communication takes place. After all, the image and movement are immediately shown.

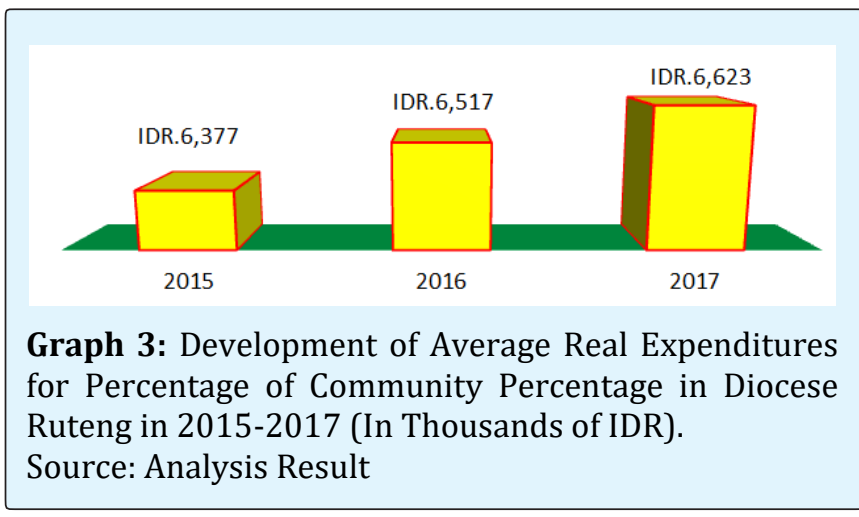

Economic resources in the form of real expenditure per capita have the opportunity to access educational resources, markets for goods and services, and health, 


\section{Journal of Quality in Health Care \& Economics}

ultimately contributing to the economic growth of a region. Increasing the quality of human resources demonstrated through HDI is a hope for all parties. The church which has delivered the civilization of society in Diocese Ruteng with local governments in three districts is expected to sit together and work synergistically to bring Catholics to a more prosperous level in the future. Therefore, accelerative and effective strategies and policies are needed to boost the quality of human resources in Diocese Ruteng which are competitive and competitive by using the available resources.

\section{Strategy and Policy}

The economy of the people: The economic development strategy as one of the decisive pillars of increasing the HDI in the Diocese Ruteng region by strengthening the economy of agro-based people. Policy is carried out through;

1. Building a micro credit institution for the poor with a system to encourage the people to be able to help themselves, because actually poor people have hidden abilities that have not been exploited

2. Developing community economic empowerment by means of human development, community development, business development and mentoring by independent professional groups

3. Creating rural eco-economic business packages towards rural independence, environmental sustainability, rural ecotourism. For example: organic compost business packages, organic farming packages, rural energy packages

4. Exciting informal businesses based on rural microenterprises

5. Increasing purchasing power is not just an economic problem, but also social, cultural and environmental problems. It needs to be improved by the Simple Living Community Movement, the culture is not consumptive, no exception is applied to all layers of society who are emulated by leaders

6. Mobilize reforestation, reforestation, restoration of protected areas, catchment blood in springs of irrigation sources and drinking water

7. Development of labor intensive scale development accompanied by independent professional institutions, and always audited transparently [19].

Education: There are 3 main strategies in the field of education to improve the HDI, namely: equity and expansion of access, improvement in quality and relevance, and governance, accountability and public imaging. The description is through policy;

1. Increasing access to quality Secondary Education;
2. Strengthening the role of the private sector in providing quality early childhood, basic and secondary education services

3. Development of facilities and infrastructure for school libraries and at every level of education;

4. Expansion of access to general and vocational primary and secondary education

5. Improvement of learning facilities and infrastructure facilities

6. Increasing the role of the private sector in the education sector

7. Provision of scholarship budgets in diosis Ruteng and government budgets

8. Developing the Sint Paulus Ruteng University and building partnerships with reputable State and Private Universities

9. Provision of facilities and infrastructure to support learning quality

10. Development of learning quality and quality of teaching staff

11. Development of transparent and accountable education governance

12. Management of an accountable national education curriculum and provision of supporting facilities and infrastructure

13. Development of public library facilities and infrastructure in each sub-district and village

14. Sports Coaching in superior sports

15. Guiding Scouts and Youth Organizations and Scouts

16. Development of vocational training centers and improvement of education and training in the formation of workforce competencies in various business fields [19].

Health Sector: Health development policies in Diocese Ruteng in the period with the following policies

1. Improvement of Health Efforts, consisting of Individual Health Enterprises and Public Health Enterprises, through

- Improving governance of Ben Mboi Hospital as for secondary referral services

- Improvement of community health centre facilities and infrastructure, integrated service post as the center of primary health services in order to provide optimal and equitable services for rural communities

- Improving the nutritional status of the community, especially the poor, infants, toddlers, pregnant women, nursing mothers, and the elderly population

- Access to quality maternal, child, adolescent and elderly health services 


\section{Journal of Quality in Health Care \& Economics}

- Improving control of infectious and non-communicable diseases and environmental sanitation

2. Management Sub-System, Health Information and Regulation, through

- Strengthening managerial capacity in the health office, community health centre, integrated service post

- Strengthening the Regional Health Information System, reporting system at the Regional General Hospital and at community health centre

- Compilation of health regulations at the district, and village level

- Increasing supervision and guidance as well as training health workers and improving the coordination of health information systems

3. Health Human Resources Sub System, through;

- Improving the quality of the health Human Resources System through Distance Education which enables health workers working in health care facilities without leaving the workplace

- Increase in number, type of Health Human Resource System as needed to achieve minimum service standards

- Equitable distribution of the Health Human Resource System to health service centers in all Diocese Ruteng

- Providing fair and transparent incentives (medical services)

4. Pharmaceutical Supply Sub Systems, Health and Food Devices, through

- Provision of essential medicines and guarantee access to medicines for the community

- Repair and calibration of health equipment and facilities and laboratories to support health services

- Supervision of food products and food containing hazardous ingredients

- Supervision of drug sales and distribution

5. Health Financing Sub-System, through

- Coordination of various health financing sources in the context of efficiency, and effectiveness of the health budget

- Balance of health financing in the Budget between promotive, preventive, curative, and rehabilitative

6. Sub-System for Community Empowerment through

- Revitalization and development of Community Based Health Efforts (posyandu, desa siaga)

- Changes in the paradigm of kinship in financing the care of sick members

- Strengthening the capacity of customary, religious and community institutions in effective and integrated health financing and referral systems

- Promotion to create a Clean and Healthy Life Behavior in the community
7. Sub-System for Research and Development of Health Science \& Technology, through

- Improvement of research activities and development of evidence-based evidence-based policy

- Research on the rates of health services based on the ability and willingness to pay the community

- Institutional strengthening and Human Resource Systems in the field of reliable and professional researchers [17].

\section{Conclusion}

The position of the HDI as one measure of the role of the Catholic church in Diocese Ruteng since 1912. The challenge of changing behavior of people formed by cyber technology makes the church and its hierarchy together with regional government officials a counterweight so that the Catholic faith and the development of civilization do not trade off each other others.

The emphasis on sacramental service by monks as a core service is still being improved, but it needs to be clarified services that touch the dimensions of education, health, and economic strengthening so that the Catholic church is not abandoned by the people in the midst of infiltration and acculturation of foreign cultures that conflict with church culture.

Increased participation and the role of the people and their leaders in managing the challenges of postmodern globalization should be an opportunity for the continued existence of the Catholic Church in the territory Diocese Ruteng.

\section{Research Limitations}

Analysis of the role of the Catholic church increases human resources in the Diocese Ruteng measured by the HDI through three indicators; average purchasing power, average length of schooling, and life expectancy. Researchers recognize that this analysis has limitations because it excludes the role of the government sector, NGOs, non-Catholic religious institutions, and individual and community awareness to improve the quality of human resources in the diocese Ruteng over the past 100 years.

The limitations of the scientific analysis of writing this article provide space for other researchers to reveal the role of other sectors in improving the quality of human resources in the diocese Ruteng. 


\section{Acknowledgment}

Appreciation are given to; 1: Chancellor of the University of Citra Bangsa who has given space and time for the author to write this scientific article; 2: Chief of Central Bureau of Statistics at East Nusa Tenggara; 3: Chief of the Local and National Period Media as resource who have presented secondary data; 4: Bishop and missionary of Diocese Ruteng who have helped complete the writing of this article.

\section{Conflict of Interest}

The author has no freedom and conflict of interest at this writing. There is no harm to his privacy as a public official in the publication of this article in a journal that is willing to publish it.

\section{References}

1. Diocese Ruteng (2017) Roma Catholic Diocese of Ruteng. Wikipedia.

2. (2019)Roman Catholic of Diocese Ruteng. Religion Office East Nusa Tenggara.

3. (2018) East Nusa Tenggara in Figures Central Bureau Statistic of East Nusa Tenggara.

4. Van Dijk (1993) Principles of Critical Discourse Analysis. Discourse \& Society, Sage Journals 4(2): 249-283.

5. (2016) Church and Politics in Indonesia. Leimena Institute.

6. (2018) Church and State of the Republic of Indonesia.

7. (2019) Industrial Revolution 4.0: Definition, History, Characteristics and Application. Journal of Manajemen.
8. Setiawan SRD (2018) Indonesia's Competitiveness Rating Increases to Position 45.

9. Gerintya S (2019) Indonesia's Education Index is Low, Competitiveness is Weak.

10. (2017) Average School Length. Central Bureau Statistic of Indonesia.

11. (2018) The percentage of poor people in March 2018 fell to 9.82 percent. Central Bureau Statistic of Indonesia.

12. Novie (2009) Poverty and how to overcome it. Emission, preach the Gospel throughout Indonesia.

13. Sanidam KY (2017) The Missionary Role of Societas Verbi Devini in Community Development in Manggarai 1913-1965. UNY Student Journal.

14. (2019) Building the Synergy of Catholic Educational Institutions. Living Catholic.

15. (2018). Human Development Index in 2017. Central Bureau Statistic of Indonesia, Republic of Indonesia.

16. (2018) East Nusa Tenggara in Figures 2018. Central Bureau Statistic NTT.

17. Salesman F, Tapung M (2016) Human Development Index in Manggarai Regency in 2015. Results of the Research Collaboration with the 2015 Manggarai Bappeda.

18. Johnston MP (2014) Secondary Data Analysis: A Method that which a Time Has Come. Quantitative and Qualitative Methods in Library (QQML) 3(3): 619-626.

19. Dunn NW (2000) Introduction to Public Policy Analysis. Translation. 